\title{
Pheochromocytoma of the Urinary Bladder Revealed with Cerebral Hemorrhage
}

\author{
Hisato Moritani, Masahiko Sakamoto, Yasuyuki Yoshida, Hiroshi Nasu, Ryosuke Nemoto* and Isao NaKamura*
}

\begin{abstract}
The case was a 51-year-old man, who has been undergoing treatment with oral medication for hypertension for three years. The patient was admitted to the author's clinic for hemorrhage in the left putamen. He was diagnosed as having primary pheochromocytoma of the bladder from such symptoms as paroxysmal blood pressure elevation after urination, mild increase in catecholamine levels before and after urination, and from the results of ${ }^{131}$ I-MIBG scintigraphy, and cystoscopy, and underwent excision of the bladder tumor. Upon endocrinological examination, only mild increases in catecholamine levels were found. Therefore, constant monitoring of blood pressure and ${ }^{131}$ I-MIBG scintigraphy were useful for a definitive diagnose.

(Internal Medicine 40: 638-642, 2001)
\end{abstract}

Key words: secondary hypertension, extra-adrenal endocrine neoplasia, cerebrovascular complication, noradrenaline

\section{Introduction}

Among those diseases that are followed by secondary hypertension, pheochromocytoma is considered to often be accompanied by complications in organs, however, relatively few cases with complications of cerebral hemorrhage have been reported. We encountered a case of primary pheochromocytoma of the bladder that was found casually with occurrence of cerebral hemorrhage. Although the hypertension in this patient came in the form of paroxysmal attacks only during urination, elevation of plasma catecholamine levels with paroxysmal attacks was mild. Since these findings are of great interest, we reported them here.

\section{Case Report}

A 51-year-old man suddenly developed hemiplegia on the right side of the body while driving his car on the morning of June 5, 1996, and he came to the emergency dispensary of the author's clinic. When he came to the author's clinic, he was diagnosed with hemorrhage in the left putamen on the brain CT (Fig. 1) with blood pressure of $164 / 144 \mathrm{mmHg}$, and was admitted to the department of Neurosurgery. Furthermore, he felt micturition while driving his private car. The patient had been treated with $20 \mathrm{mg} /$ day of propranolol orally for hypertension in a neighboring clinic since 1993.

There was nothing noteworthy in his family history. Since the day of admission, dull headache, palpitation, and blood pressure rise (maximum $300 / 140 \mathrm{mmHg}$ ) were observed after urination in the morning, therefore, the patient was transferred to the department of Cardiology for workup on these changes on August 10,1996. On the physiological findings, blood pressure in the daytime was $114 / 80 \mathrm{mmHg}$, pulse rate was $64 / \mathrm{min}$, body temperature was $35.9^{\circ} \mathrm{C}$, and no skin abnormality was found. In the upper and lower limbs of the right side, a decrease in muscular power by MMT 5-15 was observed. On laboratory tests, urinary protein was $( \pm)$ and occult blood was (-), and the results obtained in the blood test and biochemical test did not show any abnormality. No sign of cardiomegaly was observed on chest radiography, ECG, and ultrasound cardiography. Ophthalmoscopic examination revealed $\mathrm{H} 2 \mathrm{~S} 2$.

Blood pressure was measured continuously from the time of rising, because the complaint of dull headache and palpitation was given by the patient only after urination in the morning. Due to blood pressure elevation in the form of paroxysmal attack after urination, pheochromocytoma was suspected. On an endocrinological test with the blood samples that were collected in the morning, when his blood pressure was high (Table 1), a mild elevation was found in plasma noradrenaline at 0.80 $\mathrm{ng} / \mathrm{ml}$, urinary noradrenalin $145.8 \mathrm{mg} / \mathrm{day}$, urinary normethanephline $0.89 \mathrm{mg} / \mathrm{day}$, and urinary vanillylmandelic acid (VMA) $5.44 \mathrm{mg} /$ day. Plasma noradrenaline levels before and after urination changed from $0.61 \mathrm{ng} / \mathrm{ml}$ to $0.90 \mathrm{ng} / \mathrm{ml}$ (normal level: 0.10 to $0.41 \mathrm{ng} / \mathrm{ml}$ ). Plasma noradrenaline levels in the daytime when the blood pressure was normal, presented normal levels (0.18-0.29 ng/ml). ${ }^{131} \mathrm{I}-\mathrm{MIBG}$ scintigraphy (Fig. 2A) after urination was performed and images of abnormal accu-

From the Department of Cardiology and *the Department of Urology, Tottori Prefectural Central Hospital, Tottori

Received for publication September 4, 2000; Accepted for publication January 20, 2001

Reprint requests should be addressed to Dr. Hisato Moritani, the Department of Cardiology, Tottori Prefectural Central Hospital, 730 Ezu, Tottori-shi, Tottori 680-0901 
mulation in the bladder were obtained. On cystoscopy (Fig. 2B), a submucosal tumor of $23 \times 21 \mathrm{~mm}$ in diameter was found on the top of the bladder. Abdominal contrast enhanced CT (Fig. 3A) showed no abnormality on the adrenal glands and para-aorta, however presented a shadow of a solid tumor that

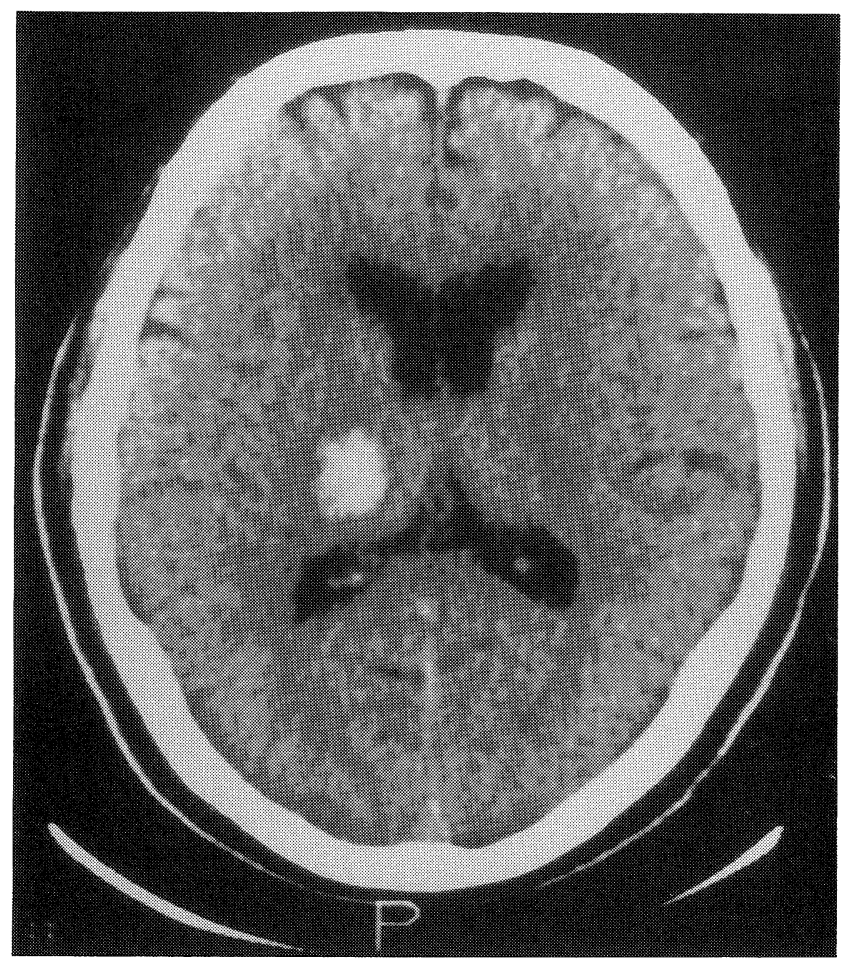

Figure 1. Brain CT showed left putaminal hemorrhage on admission. had a region of low intensity in the internal portion on the wall of the bladder, and MRI also showed (T1 weighted images, sagittal section, Fig. 3B) a shadow of a solid tumor that had a region of low intensity in internal portion. Based on the results described above, the lesions were diagnosed as primary pheochromocytoma of the bladder. Hypertension in the form of paroxysmal attacks was adequately controlled with $\alpha_{1}$-blocker (Doxazosin $4 \mathrm{mg} /$ day), $\beta$-blocker (Propranolol $30 \mathrm{mg} / \mathrm{day}$ ), and $\mathrm{Ca}^{2+}$ antagonist (Amlodipine $5 \mathrm{mg} /$ day), and excision of tumor was performed in the department of Urology in the author's clinic on September 8, 1996. Under general anesthesia, segmentectomy of the bladder including a tumor was carried out by midline incision of the pubic region. A tumor was found in the wall of the bladder and no infiltration or metastasis into the ambient tissues was confirmed. The tumor in the excised sample (Fig. 4) was revealed to be $20 \times 20 \mathrm{~mm}$ in diameter, it's cut surface was white, and elasticity was soft, and it had some necrotic tissue internally. Histopathological findings (Fig. 5) of the sample presented solid proliferation of round cells of small size, and chromogranin staining was shown to be positive. Blood pressure elevation after urination disappeared after the operation, and catecholamine levels returned to normal. Thereafter, the patient has been observed as an outpatient, and has been no recurrence of the tumor as of June 2000. The possibility of multiple endocrine neoplasia (MEN) was negative.

\section{Discussion}

Primary pheochromocytoma of the bladder has been thought to develop from retention of chromaffin tissues in the sympathetic plexuses in the wall of the bladder (1). This disease is a comparatively rare one and the incidence of the disease is about $1 \%$ of all pheochromocytoma and about $11 \%$ of exadrenal pheochromocytomas (2). According to Noguchi et al (3), 52 cases

Table 1. Endocrinological Findings

\begin{tabular}{|c|c|c|c|c|c|}
\hline ACTH & $35.6 \mathrm{pg} / \mathrm{ml}$ & Cortisol & $16.6 \mu \mathrm{g} / \mathrm{dl}$ & $75 \mathrm{~g}$ OGTT & normal pattern \\
\hline TSH & $2.31 \mu \mathrm{U} / \mathrm{ml}$ & PRA & $0.9 \mathrm{ng} / \mathrm{ml} / \mathrm{h}$ & & \\
\hline PRL & $4.1 \mathrm{ng} / \mathrm{ml}$ & Aldsterone & $14.0 \mathrm{ng} / \mathrm{dl}$ & Testosterone & $316.2 \mathrm{ng} / \mathrm{dl}$ \\
\hline $\mathrm{HGH}$ & $0.3 \mathrm{ng} / \mathrm{ml}$ & u-17-OHCS & $7.3 \mathrm{mg} /$ day & Estradiol & $15.9 \mathrm{pg} / \mathrm{ml}$ \\
\hline LH & $4.2 \mathrm{mIU} / \mathrm{ml}$ & $\mathrm{u}-17-\mathrm{KS}$ & $13.5 \mathrm{mg} /$ day & & \\
\hline FSH & $5.0 \mathrm{mIU} / \mathrm{ml}$ & Adrenaline & $0.04 \mathrm{ng} / \mathrm{ml}$ & Endothelin-1 & $1.2 \mathrm{pg} / \mathrm{ml}$ \\
\hline & & Noradrenaline & $0.80 \mathrm{ng} / \mathrm{ml}$ & PTHrP & $28.0 \mathrm{pmol} / l$ \\
\hline $\mathrm{FT}_{3}$ & $4.0 \mathrm{pg} / \mathrm{ml}$ & Dopamine & $0.01 \mathrm{ng} / \mathrm{ml}$ & IL-6 & not measured \\
\hline $\mathrm{FT}_{4}$ & $1.3 \mathrm{ng} / \mathrm{dl}$ & u-Adrenaline & $7.0 \mu \mathrm{g} / \mathrm{day}$ & & \\
\hline & & u-Noradrenaline & $145.8 \mu \mathrm{g} /$ day & \multirow{8}{*}{\multicolumn{2}{|c|}{$\begin{array}{l}\text { pre \& post urination } \\
\text { Adrenaline: } 0.06 \rightarrow 0.10 \mathrm{ng} / \mathrm{ml} \\
\quad \text { (normal range }<0.12 \mathrm{ng} / \mathrm{ml} \text { ) } \\
\text { Noradrenaline: } 0.61 \rightarrow 0.90 \mathrm{ng} / \mathrm{ml} \\
\quad \text { (normal range } 0.10-0.41 \mathrm{ng} / \mathrm{ml} \text { ) }\end{array}$}} \\
\hline PTH-C & $<0.3 \mathrm{ng} / \mathrm{ml}$ & (normal range & $26.0-121.0 \mu \mathrm{g} /$ day) & & \\
\hline PTH-intact & $19.0 \mathrm{pg} / \mathrm{ml}$ & u-Dopamine & $666 \mu \mathrm{g} /$ day & & \\
\hline H-PTH & $271 \mathrm{pg} / \mathrm{ml}$ & u-Metanephrine & $0.08 \mathrm{mg} / \mathrm{day}$ & & \\
\hline \multirow[t]{4}{*}{ Calcitonin } & $23 \mathrm{pg} / \mathrm{ml}$ & u-Normetanephrine & $0.89 \mathrm{mg} / \mathrm{day}$ & & \\
\hline & & (normal range & $0.07-0.26 \mathrm{mg} /$ day) & & \\
\hline & & u-VMA & $5.44 \mathrm{mg} /$ day & & \\
\hline & & (normal range & $1.30-5.10 \mathrm{mg} /$ day) & & \\
\hline
\end{tabular}

※PRA: plasma renin activity, VMA: vanillylmandelic acid, PTHrP: parathyroid hormone-related peptide, IL-6: Interleukin6. 


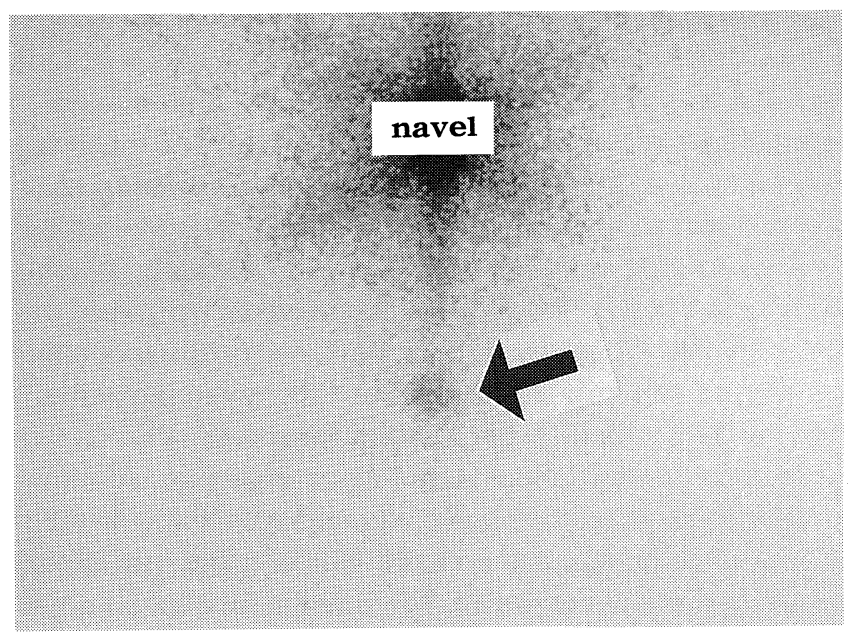

A

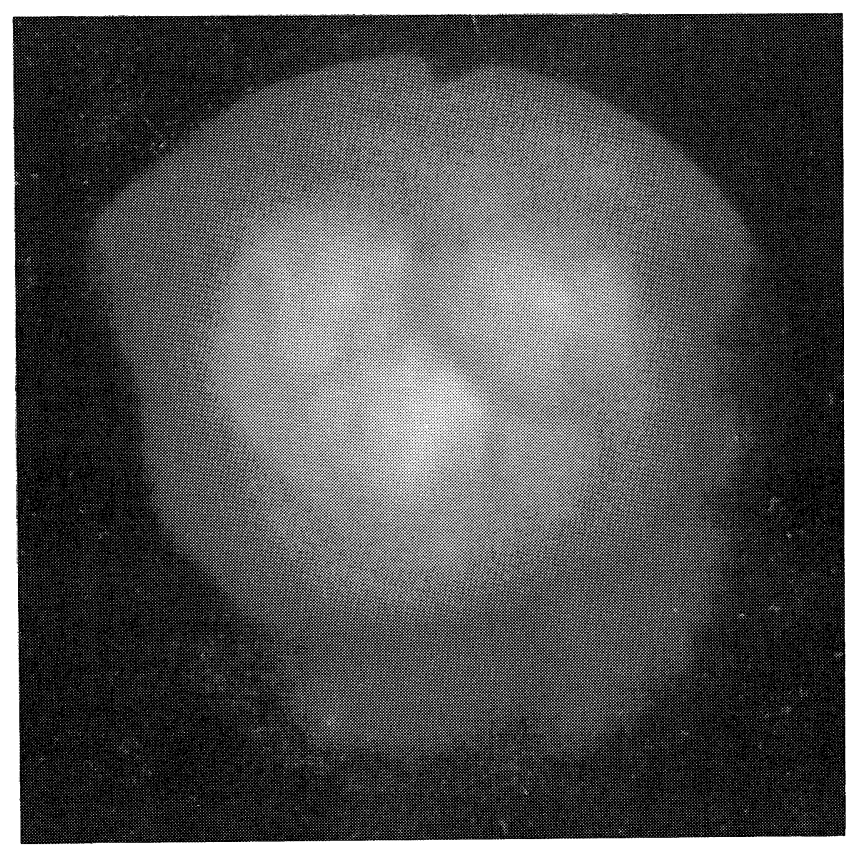

B

Figure 2. A: ${ }^{131}$ I-metaiodobenzylguanidine (MIBG) scintigraphy showed an abnormal accumulation pattern in the vesical region (arrow). B: Cystoscopy revealed a submucosal tumor measuring $23 \times 21 \mathrm{~mm}$ at the top of the bladder.

have been reported in Japan. As a diagnostic method of the cases that are suspected to be pheochromocytoma, considering the course of clinical symptoms, measurement of urinary methanephrine concentration has been considered useful for screening. However, false-positive cases that show an increase in catecholamine levels in essential hypertension and cerebral hemorrhage, or on the contrary, false-negative cases that do not show an increase in catecholamine levels in pheochromocy-

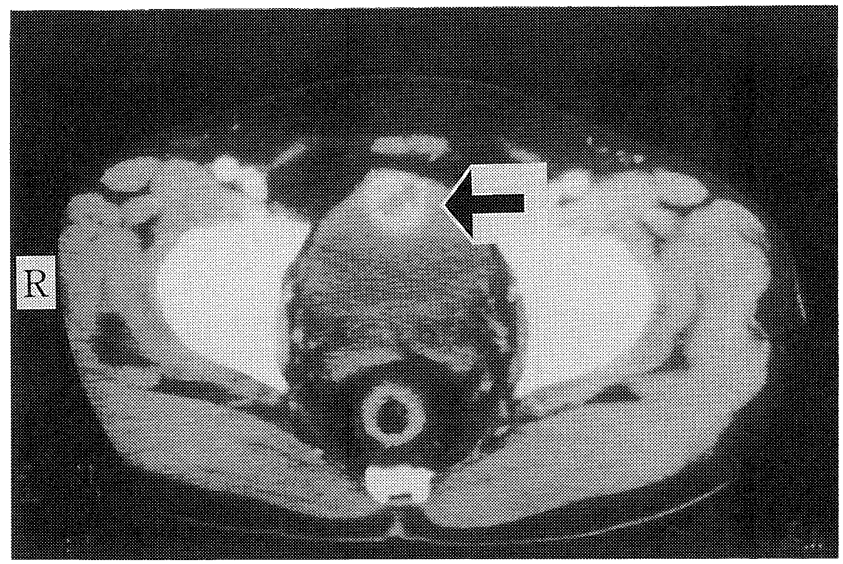

A

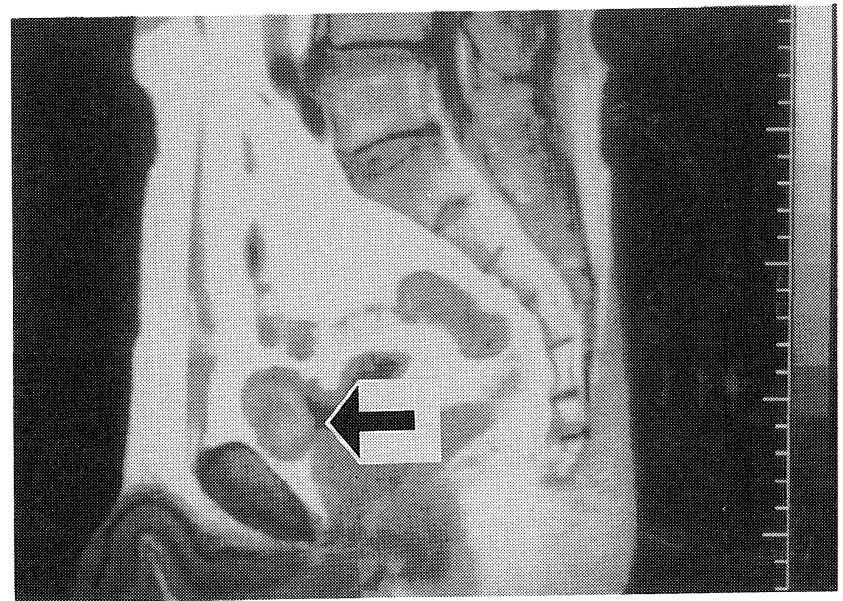

B

Figure 3. A: On abdominal CT, the adrenal gland and paraaorta were normal and a massive tumor shadow showing a low density area inside was found on the bladder wall (arrow). B: MRI (T1-weighted image, sagittal section) revealed a tumor shadow of low intensity (arrow).

toma, pose some problems. Yokoyama and Tsuji (4) reported the usefulness of the methoclopropamide loading-test and ${ }^{131} \mathrm{I}$ MIBG scintigraphy, but also reported that even though both of these methods have $100 \%$ specificity, they lack sufficient sensitivity. In recent years, studies of measurements of plasma methanephrine have been reported as a new method for diagnosis of pheochromocytoma. According to Lenders et al (5), the sensitivity of plasma catecholamines and urinary methanephrine to pheochromocytoma is $85 \%$ and $89 \%$, respectively, but the sensitivity of plasma methanephrine is $100 \%$, therefore, they reported the usefulness of plasma methanephrine. On the other hand, a false-negative case of plasma methanephrine was also reported (6). When the measurement becomes commonly used in the future, this may be expected to 

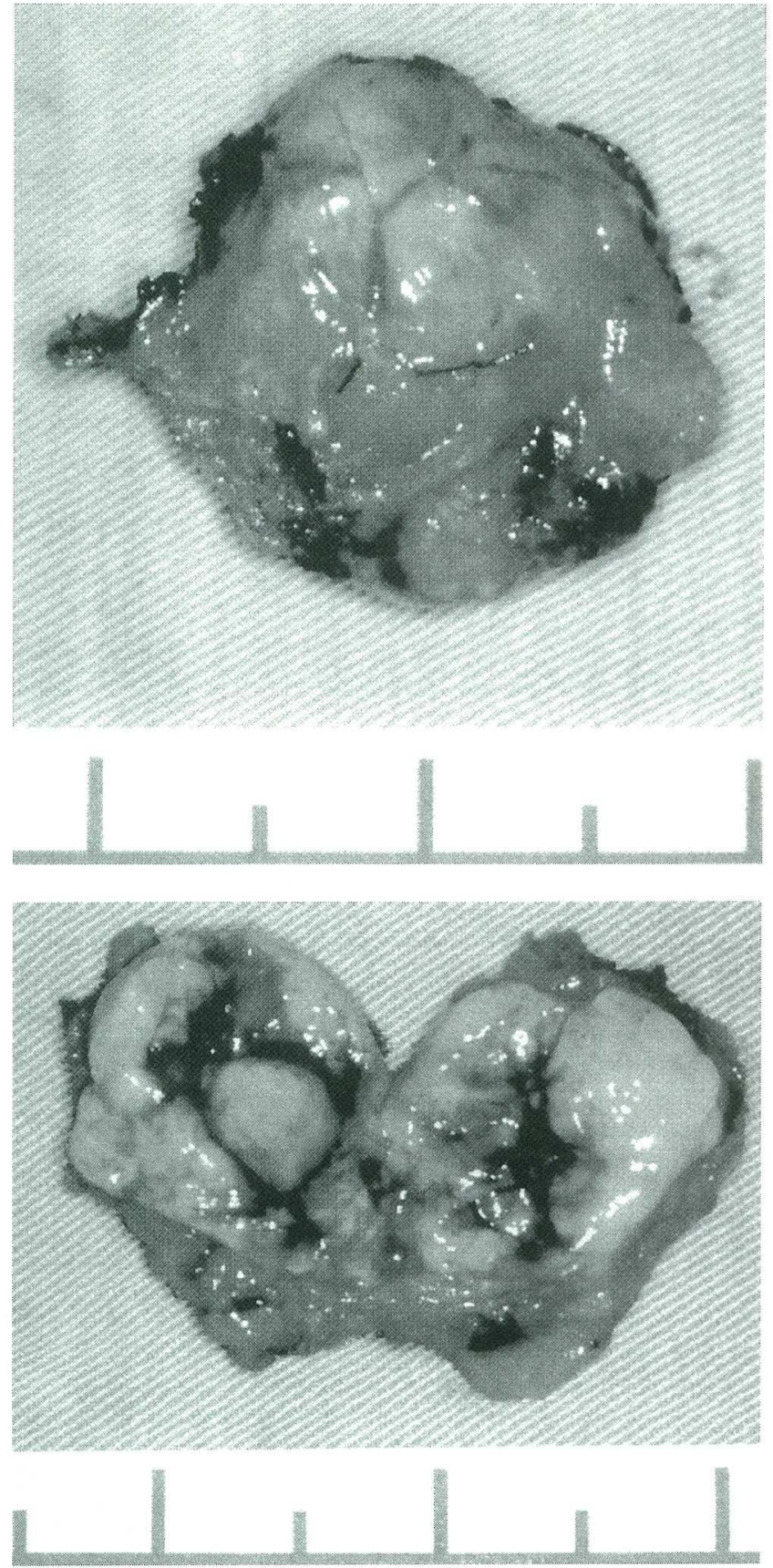

Figure 4. On examination of resected specimens, the tumor measured $20 \times 20 \mathrm{~mm}$, was soft and elastic in consistency with a white cut surface, showing necrotic tissues inside.

be a useful method. On diagnosis of regions, the usefulness of PET with 2-[fluorine-18]-fluoro-2-deoxy-D-glucose (FDG) for a negative case in ${ }^{131}$ I-MIBG scintigraphy, was also reported (7). The present case showed blood pressure elevation in the form of paroxysmal attacks, in other words, micturition attacks, which occur only during urination and which is peculiar to primary pheochromocytoma of the bladder. However, the case

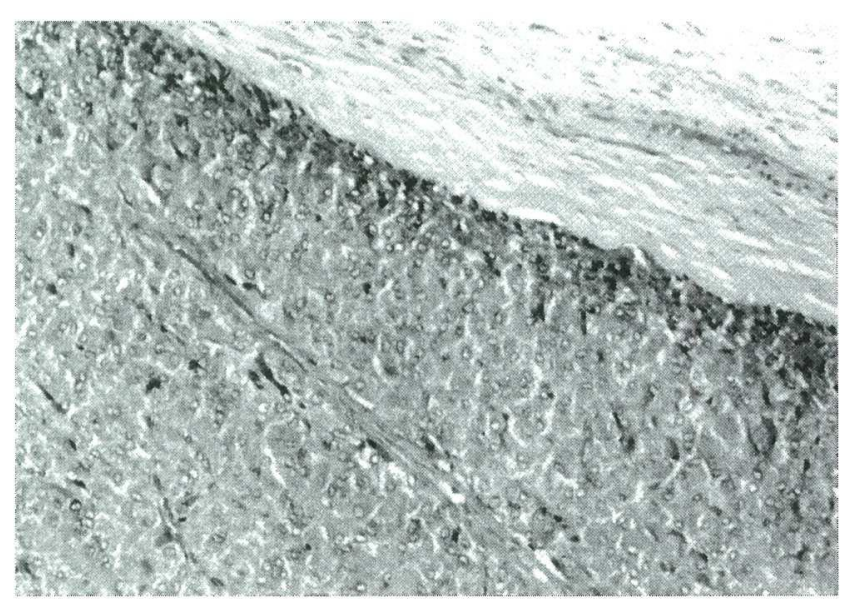

A

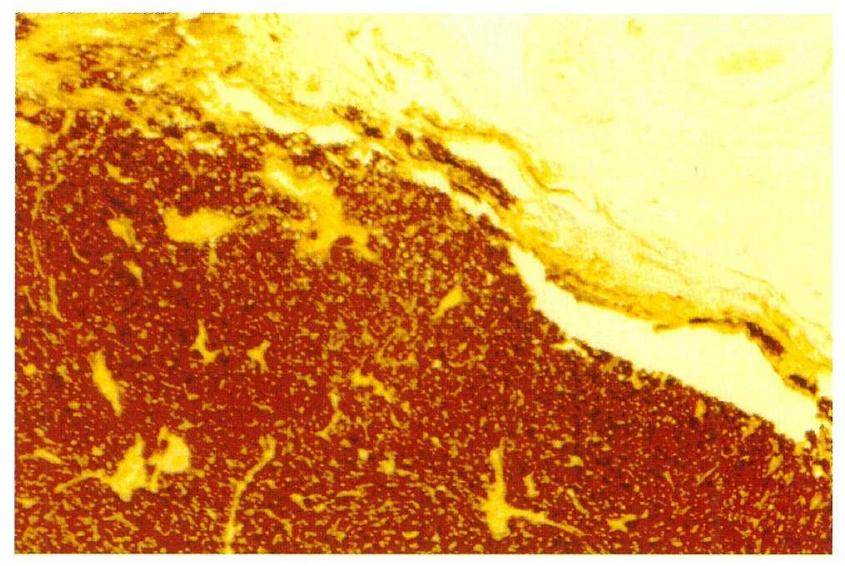

B

Figure 5. On histopathological examination, small round cells showed a sold proliferation $(A, H E$ stain, $\times 100)$, and were positive for chromogranin staining $(B$, chromogranin stain, $\times 40)$.

only induced mild elevation of catecholamine levels upon endocrinological examination. Methoclopropamide loading test could not be performed due to cerebral hemorrhage, and a clonidine-inhibiting test was not carried out due to a low level of plasma catecholamines. For the diagnosis of the present case, constant monitoring of blood pressure that was reported by Fujishima et al (8) was useful for discrimination of morning surge, and for diagnosis of regions, ${ }^{131}$ I-MIBG scintigraphy was useful.

Cerebrovascular disease is a serious complication but its incidence is comparatively low, and Thomas et al (9) reported that cerebral infarction was found in $3 \%$ and cerebral hemorrhage was in $2 \%$ out of 100 studied cases. According to Sutton et al (10), $13 \%$ of 54 autopsied cases died of cerebrovascular disease. Reports on complications of cerebral hemorrhage (11, 12) are also occasionally found in Japan, but compared with 


\section{Moritani et al}

general hypertensive cerebral hemorrhage, this disease is found more often in a comparatively younger age group (24-54 years old), which is similar to the range of ages where pheochromocytoma often develops. Therefore, when cerebral hemorrhage was found in the younger group, development of this disease must be suspected. The symptoms of hypertension in the patients with pheochromocytoma may be classified mainly into constant type, paroxysmal type, and normal blood pressure type (13). Although there has been no report on the comparison of incidences of cerebral hemorrhage in each type, it was revealed that even the paroxysmal type, which shows blood pressure rise only during urination, might be able to trigger cerebral hemorrhage.

Miura et al (13) reported that plasma catecholamine levels in pheochromocytoma were $1,790 \pm 2,140 \mathrm{pg} / \mathrm{ml}$ on average for males with paroxysmal type, and $856 \pm 741 \mathrm{pg} / \mathrm{ml}$ on average for males with normal blood pressure type. However, in the present case, catecholamine level elevation was remarkably slight (maximum plasma noradrenaline level during urination was $0.90 \mathrm{ng} / \mathrm{ml}$, which was two times higher than that of normal level) in comparison with blood pressure elevation. Among the cases reported (14), contrary to the present case, there were some patients who did not show high blood pressure, even though their catecholamine levels were high. Reduction of the sensitivity of catecholamines receptors is considered the cause of this phenomenon (15). Though sensitivity to catecholamines could not be confirmed in the present case because of lack of loading test owing to cerebral hemorrhage, it was speculated that the sensitivity of catecholamines receptors might be extremely high. It has been reported that in pheochromocytoma, $\alpha$-receptors and $\beta$-receptors in the cardiovascular system generally may be down regulated to excessive catecholamines (16, 17), and the enhanced sensitivity in this case was considered quite interesting. A study on the sensitivity of this case to catecholamines is scheduled after obtaining consent of the patient himself. Involvement of endothelin in blood pressure elevation in pheochromocytoma has also been reported (18), but the endothelin level was normal in the present case.

In conclusion, we encountered a case of primary pheochromocytoma of the bladder that was found coincidentally with the occurrence of cerebral hemorrhage. Elevation of plasma catecholamines level was mild and was paroxysmal, and ${ }^{131} \mathrm{I}-$ MIBG scintigraphy and constant monitoring of blood pressure was discovered to be useful for its diagnosis.

\section{References}

1) Zimmermann IJ, Biron RE, MacMahon HE. Pheochromocytoma of the urinary bladder. N Engl J Med 249: 25-26, 1953.

2) Fries JG, Chamberlin JA. Extra-adrenal pheochromocytoma: Literature review and report of a cervical pheochromocytoma. Surgery 63: 268 279, 1968.

3) Noguchi A, Hamamoto Y, Minoshima K, et al. Pheochromocytoma of the urinary bladder: A case report. Hinyokika kiyo 45: 721-723, 1999 (Abstract in English).

4) Yokoyama H, Tsuji Y. Noninvasive screening for pheochromocytoma in patients with an incidentally discovered adrenal mass: Usefulness of provocative test with metoclopramide and ${ }^{131} \mathrm{I}$-metaiodobenzylguanidine scintigraphy. Hinyokika kiyo 45: 677-680, 1999 (in Japanese).

5) Lenders JWM, Keiser HR, Goldstein DS, et al. Plasma Metanephrines in the diagnosis of pheochromocytoma. Ann Intern Med 123: 101-109, 1995 (see comments).

6) Krakoff LR. Searching for pheochromocytoma: A new and better test? Ann Intern Med 123: 150-151, 1995 (editorial; comment).

7) Shulkin BL, Thompson NW, Shapiro B, Francis IR, Sisson JC. Pheochromocytoma: Imaging with 2-[Fluorine-18] fluoro-2-deoxy-D-glucose PET $^{1}$. Radiology 212: 35-41, 1999.

8) Fujishima S, Abe I, Kaseda S, et al. Ambulatory blood pressure monitoring in diagnosing a pheochromocyotoma of the urinary bladder. A case report. Angiology 48: 655-658, 1997.

9) Thomas JE, Rooke ED, Kvale WF. The neurologist's experience with pheochromocytoma: A review of 100 cases. JAMA 197: 754-758, 1966.

10) Sutton MG, Sheps SG, Lie JT. Prevalence of clinically unsuspected pheochromocyotoma: Review of a 50-year autopsy series. Mayo Clin Proc 56: 354-360, 1981.

11) Murotani N, Kobayashi T, Kimura $Y$, et al. A case of pheochromocyotoma associated with von Recklinghausen's disease revealed by cerebral hemorrhage. Endocr Surg 10: 257-261, 1993 (Abstract in English).

12) Onishi H, Mori K, Kurachi M, Kano A, Ito H, Yamamoto S. Cerebellar hemorrhage associated with pheochromocyotoma. Kyukyuigaku 12: 1681-1684, 1988 (in Japanese).

13) Miura $Y$, Noahiro T, Kusakari T, et al. Hypertension in pheochromocyotoma. Hormon To Rinsho 42: 277-282, 1994 (in Japanese).

14) Mori K, Shigetomi S, Fukuchi S. A case of pheochromocytoma of the urinary bladder. Naika 68: 789-791, 1991 (in Japanese).

15) Kawai K, Kimura S, Miyamoto J, et al. A case of multiple extra-adrenal pheochromocytomas. Endocrinol Jpn 26: 693-696, 1979.

16) Snavely MD, Motulsky HJ, Moustafa E, Mahan LC, Insel PA. $\beta$-adrenergic receptor subtypes in the rat renal cortex: Selective regulation of $\beta_{1^{-}}$ adrenergic receptors by pheochromocytoma. Cir Res 51: 504-513, 1982.

17) Snavely MD, Mahan LC, O'Connor DT, Insel PA. Selective down-regulation of adrenergic receptor subtypes in tissues from rats with pheochromocytoma. Endocrinology 113: 354-361, 1983.

18) Letizia C, De Toma G, Cerci S, et al. Plasma endothelin-1 levels in patients with aldosterone-producing adenoma and pheochromocytoma. Clin Exp Hypertens 18: 921-931, 1996. 